\title{
Visit to the Faculty of Law in the University of Jos, Nigeria
}

- by Gerry Power, Access Librarian, Institute of Advanced Legal Studies

\section{Travelling to Jos}

I travelled from London to Jos, Nigeria, in April 2006 to help the Law Faculty there to deliver two workshops entitled Using the Internet as a Research and Teaching Tool for Academics, Lawyers and Judges. My 6-hour flight from Heathrow took me to the airport of Abuja, Nigeria's federal capital, situated in the centre of the country. Then a 3-hour car journey brought me into pleasant hilly upland country, where I reached the city of Jos, situated north-east of Abuja. For a first-time visitor, Nigeria is an extraordinary country, and each hour brings a new surprise or wonder: amazing road traffic, noisy bustling markets, intense heat, sun-baked landscapes, police checkpoints along the highway, heated debate about constitutional affairs, and crowds of people, in Africa's most populous country. One thing I grew accustomed to quickly was the friendliness and courtesy of the many people I met during my trip. This made for a very pleasant experience and always helped when things got difficult.

The opportunity to visit Jos and help with the workshop came in a roundabout way. IALS Librarian, Jules Winterton, received a request for help via the International Association of Law Libraries, in October 2005: could we send somebody to Jos to do some training? I happily volunteered, and was pleased to make e-mail contact with Dr Philip Ostien in the Faculty of Law in Jos in late October. During the next few months, Dr Ostien and I exchanged many e-mails to work out a two-week programme for Spring 2006. The IALS agreed that I could take official leave in order to travel to Jos and do the training, and we fixed dates for March 2006. The University of Jos agreed to cover my travel, accommodation and other expenses in Nigeria.

During January 2006, however, the census of population for Nigeria was declared for March, which meant that no lawyer or student would be able to travel for training during the census period in March. Therefore, after further consultations between the organising committee at Jos and the IALS Library, it was agreed that my travel dates would be deferred to April, to arrive in Abjua on 13 April, and to return to London on 29 April.

\section{Jos as a legal centre}

Jos is an important legal centre, being the capital of Plateau State in Nigeria, and having the High Court for Plateau State. Jos forms a judicial division for the Nigerian Court of Appeal, for the States of Adamawa, Bauchi, Benue, Borno, Gombe, Nasarawa, Plateau, Taraba and Yobe ${ }^{1}$. The Law Faculty at the University of Jos offers undergraduate, postgraduate and research degree programmes. Many of the LLM students I met are studying part time and working either in private practise or in government service.

\footnotetext{
${ }^{1}$ See information on the Court of Appeal on Nigeria Law at http://www.nigeria-law.org
} 


\section{Aims and Objectives of the Workshops}

Jos Law Faculty expressed the need for two weeks of training, with a mixture of sessions including hands-on exercises in a computer lab, presentations and demonstrations of different databases, and informal question and answer sessions. The first week's training would be for law lecturers from different law faculties in Nigeria, whilst the second week would be targeted at judges, government officials and lawyers. The Law Faculty wanted the course content to include good free legal sources on the Internet, as well as coverage of Westlaw and Hein Online. Particular emphasis was to be placed on online access to materials about, or originating from, Nigeria.

Thus, the agreed aims and objectives of the workshops were:

Aim: to explore and develop effective ways of using the internet as a legal research tool.

Workshop objectives:

- To explore good free legal information sources on the internet by searching and browsing

- To evaluate free websites using criteria derived from the SOSIG Law Gateway (now known as Intute: $\mathrm{Law}^{2}$ )

- To explore some of the many databases in Westlaw and Hein Online, by searching and browsing

- To reflect on how useful these resources are to our work, learning, research or teaching

My main material for the practical sessions was a workbook, which I devised before travelling to Nigeria. It included exercises on free sources of Nigerian legislation and case law, searching by topic in Hein and Westlaw, and finding journal articles by authors with an affiliation in a Nigerian or other African university. Gateways to free internet sources, such as Commonlii ${ }^{3}$ and Intute: Law, also figured in the workbook.

\section{Workshop Facilities at the University of Jos Law Faculty}

The University of Jos has received a grant of US\$ 2 million from the Carnegie Corporation for the period 2003-2006, to help with ICT developments and infrastructure. This grant has brought many benefits to the University, including the setting up of an online legal research lab at the Law Faculty, which is housed in a room adjacent to the Law Library.

Twelve PCs are networked, with additional capacity for laptops. All are protected by an uninterrupted power supply, essential in areas subject to power cuts or surges. A printer and good data projector are also available. The Law Faculty currently subscribes to both Westlaw and Hein Online.

\footnotetext{
${ }^{2}$ http://www.intute.ac.uk/socialsciences/law/

${ }^{3}$ Commonlii at http://www.commonlii.org/
} 
The lab is staffed by some six interns, in a regular rota, who are $4^{\text {th }}$ or final year undergraduate law students who have very good ICT skills and who have all been trained on Hein and Westlaw. The interns work closely with Dr Ostien, the ICT coordinator of the Law Faculty, and the University Library has agreed to pay them 5,000 Naira per month as library assistants for their duties in the lab.

The lab is open to postgraduate law students and lecturers from Jos, but not many people use it yet, because many staff and students do not yet know how to search Hein and Westlaw. In practice, the interns act as search intermediaries and can agree to search the databases for students and to compile the results on printout or CD-Rom, for a small charge. The logs for searches and printouts show that many such searches are carried out.

An additional PC lab is also available in the Law Faculty, and this is popular with undergraduate students who use it, for a small charge, as an internet café, for help with surfing, WP, printing, e-mail etc. This lab attracts lots of usage. For training purposes, an extra computer lab of some 40 or more PCs is available for hire in the University Computer Centre, and this is the lab we used during the first week of training.

\section{Delivering the workshops, or what actually happened}

A total of eight paying customers turned up for the training at the beginning of week 1, comprising a number of people from Amadou Bello University, one lecturer from Abia State University, and one lecturer from the University of Uyo. This was far short of the $40+$ numbers expected, so the organising committee made the quick decision to make all of the week 1 sessions available to the Jos LLM students. This quickly brought numbers up to approximately 60 for week 1 .

Day 1 was marred by several power cuts and a resultant poor internet connection. We had a good enough morning session in the law auditorium, with some workbook exercises and class discussions considering the place of the internet in legal research, alongside other more long-term and trusted sources such as libraries, archives, colleagues and experts. To accommodate the numbers, the afternoon session was held in the lab in the Computer Centre $(40+$ PCs) but we had to abandon this afternoon session because of the problems with ICT and electricity that day.

Fortunately, days 2 and 3 of week 1 went much better. The electricity supply and internet connection proved much more reliable, thanks to the good work of technicians and other staff at the Computer Centre. The Law Faculty's interns did a wonderful job too of keeping the projector working effectively and of keeping a good stable connection to Westlaw and Hein Online for demonstration purposes during the mornings. Their help in the labs during the afternoon hands-on sessions was much appreciated. The interns help not only with technical matters but they can also help individual learners with searching and browsing techniques in the different databases. Many people attempted and completed exercises from the workbook during the afternoon sessions on days 2 and 3. However, the party from Amadou Bello Univeristy had to leave early on day 3 . Feedback from participants was quite good for week one, considering the numbers and the problems on day 1, but we did not get 
an opportunity to hand out evaluation forms. In addition to my sessions, the programme included talks from Mr Pwajok of the Computer Centre, on computer systems, and Dr Ostien, on how to develop an online legal research lab. Both $\mathrm{Mr}$ Pwajok's and Dr Ostien's respective sessions were very well received and generated lots of questions and some discussion, in both weeks 1 and 2.

For week 2, we had smaller numbers and the participants came from the Plateau State Ministry of Justice, two lecturers from the University of Lagos, the Legal Advisor of Gombe State Assembly, and a young woman doing a placement in a law school as part of her national youth service. Thus we had ten people in week 2, and we were able to keep all sessions, both morning and afternoon, in the Law Faculty's research lab. Again, with the help of the interns, we were able to deliver a 3-day workshop that tried to meet all the aims and objectives. All scheduled demonstrations and talks were delivered on time. At least two of the participants had never used a PC before, so they got lots of help from the interns in attempting some of the exercises.

Feedback from many of the participants was positive, but again we unfortunately did not hand out evaluation forms on time during week 2, as some people had to leave after lunch on the final day.

\section{Some thoughts on evaluation}

As mentioned earlier, we did not distribute evaluation forms for the workshops for various reasons. The following remarks are based in my observations and on informal feedback received from participants.

The workbook exercises worked well for many participants, but I was concerned that the people new to PCs would be left behind. Luckily, the interns were able to offer extra help to beginners to get them started with using the mouse and keyboard. Such a mixed ability group may seem very strange to those of us from better resourced parts of the globe, but many people in Nigeria have never used a PC for their work or studies. My suggestion to the organising committee was that any future workshops might put learners into two streams: beginners in the internet café lab with help from interns on the basics, and more experienced users in the law lab with lots of exercises from the workbook.

The law lab was well laid out, and I suggested to the interns that they develop some help sheets and guides to different resources, to help users. I showed them some of the many guides on legal sources available from different libraries in the UK, and suggested some posters also on good practice in using PCs, to highlight points about eye strain, posture, and ergonomics. They were also interested in developing their search techniques for Westlaw and Hein, to improve their current work as search intermediaries. So we spent one session for the interns on advanced searching.

With hindsight, the workbook could have contained some more topical exercises, e.g. top 20 sites for Africa. Participants could have spent more time evaluating websites using the form in the workbook. Also, with hindsight, I would like to have included more varied tasks for learners to allow them to track the development of their skills and knowledge over the 3-day period, e.g. do a mini project or a 5 minute presentation on day 3 . 


\section{Coming back to London ...}

I had a very busy, stimulating and tiring visit to Jos during April. The heat gets to you, even if you have lived in Africa before. I was fortunate to work with an excellent committee at the Law Faculty, and I particularly remember the help of Phil Ostien, Adamu Pam, Joash Amupitan, Benedicta Daudu and Professor Jamila Nasir. Their hospitality and help made my visit memorable. The sights and sounds of Nigeria will stay with me for a long time. 
